\section{SOI: $1.1 /$ TAS DOI: $10.15863 /$ TAS International Scientific Journal Theoretical \& Applied Science}

\author{
p-ISSN: 2308-4944 (print) e-ISSN: 2409-0085 (online) \\ Year: $2016 \quad$ Issue: 2 Volume: 34 \\ Published: 29.02.2016 http://T-Science.org
}

SECTION 9. Chemistry and chemical technology.
Abdul Jabar Kh. Atia

Department of Chemistry, College of Science, Al- Mustansiriyah University, Baghdad, Iraq

Mohammed F. Al-Marjani Department of Biology, College of Science, Al- Mustansiriyah University, Baghdad, Iraq marjani20012001@yahoo.com

Muayad Abbood Qaban Department of Chemistry, College of Science, Al- Mustansiriyah University, Baghdad, Iraq

\title{
ANTIFUNGAL ACTIVITY OF SOME NEW $\beta$-LACTAM AND IMIDAZOLE DERIVATIVES
}

\begin{abstract}
Trichophyton mentagrophytes causes a variety of infections in both animals and humans. It is a zoophilic fungus and most human diseases are contacted from animals. It is of worldwide distribution and has a very wide range of hosts. The aim of this study was to evaluate the antifungal activity of compounds of derivatives (C4) and (C7) in vivo and in vitro. The antifungal activity was determined by the agar method against T. mentagrophytes. Derivatives were synthesized by the reaction of cinnamic acid with thionyl chloride to give the corresponding acid chloride (C1). Carbohydrazide (C2) was obtained by the reaction of (C1) with hydrazine hydrate. Compound (C2) undergoes the character condensation reaction with aromatic aldehyde(4bromobenzaldehyde) in absolute ethanol gave the Schiff's base (C3). Treating a phenyl acetic acid in triethyl amine with (C3) in the presence of SOCl2 to form the appropriate $\beta$-lactams (C4). Reaction of compound (C1) with glycine in sodium hydroxide solution gave acid (C5). Oxazole derivative (C6) was synthesized by the reaction of (C5) with aromatic aldehydes (2-chlorobenzaldehyde) in acetic acid and acetic anhydride. Imidazole derivatives (C7) was synthesized by the reaction of Hydrazine hydrate with (C6) in dry benzene. The product compounds were characterized by FT-IR, U.V and IHNMR spectra.The results showed that cyclic compound had highly effect against T. mentagrophytes (in vitro) and in treatment skin infection (in vivo) when the healing was occur after 10 days compare with control.

Key words: Trichophyton mentagrophytes, $\beta$-lactams, Imidazole.

Language: English

Citation: Atia AJ, Al-Marjani MF, Qaban MA (2016) ANTIFUNGAL ACTIVITY OF SOME NEW $\beta$ LACTAM AND IMIDAZOLE DERIVATIVES. ISJ Theoretical \& Applied Science, 02 (34): 7-20.

Soi: http://s-o-i.org/1.1/TAS-02-34-2 Doi: crossef http://dx.doi.org/10.15863/TAS.2016.02.34.2
\end{abstract}

\section{Introduction}

Trichophyton is a genus of fungi, which includes the parasitic varieties that cause tinea, including athlete's foot, ringworm, jock itch, and similar infections of the nail, beard, skin and scalp. Trichophyton fungi are molds characterized by the development of both smooth-walled macro- and microconidia (Lorch et al.,2015). Trichophyton mentagrophytes is a member of a homogenous group of fungi called dermatophytes. Dermatophytes form a group of pathogenic fungi which have a marked affinity for keratin, attacking skin, hair and nails. $T$. mentagrophytes like other dermatophytes has the ability to break down or digest keratinized areas in humans, birds and other mammals [2]. Hydrolysis of keratin by keratinases is an important aspect of fungal pathogenesis. For dermatophytes to induce active infection, the arthroconidia lodging on the skin surface must be able to penetrate the stratum corneum [3]. Five different keratinolytic enzymes from ten strains of $T$. mentagrophytes have been isolated. These enzymes are known to play a role in pathogenesis of infections caused by these organisms in both humans and animals. In Nigeria, $T$. mentagrophytes has been isolated from cases of foot infections in coal miners [4] and from school children [5]. In Amsterdam, Nieboar et al. [6] isolated $T$. mentagrophytes twice as often as $T$. rubrum from industrial workers using common shower rooms. In a study of ringworm in coal miners in Britain, Gentles and Homes [7] recovered $T$. mentagrophytes alone from 224 of 346 clinical specimens, and $T$. rubrum and T. mentagrophytes from 13 specimens. Heterocyclic compounds had been receiving considerable attention due to their pharmacological and pesticidal importance [8-16]. Imidazole is an organic compound with the formula $\mathrm{C}_{3} \mathrm{H}_{4} \mathrm{~N}_{2}$ [17]. Imidazole is a monoacidic base having the ability to form crystalline salts with acids [18]. Imidazole is a 5-membered planar ring, which is 
soluble in water and other polar solvents. The compound is classified as aromatic due to the presence of a sextet of $\pi$-electrons, consisting of a pair of electrons from the protonated nitrogen atom and one from each of the remaining four atoms of the ring [19]. A $\beta$-lactam ring is a four-membered ring. A lactam is a cyclic amide. It is named as such because the nitrogen atom is attached to the $\beta$-carbon relative to the carbonyl. The simplest $\beta$-lactam possible is azetidin-2-one [20]. Up to 1970 , most $\beta$ lactam research was concerned with the penicillin and cephalosporin groups, but since then, a wide variety of structures have been described [21]. This work was carried out to determine Antifungal activity of some New $\beta$-lactam and Imidazole derivatives.

\section{Material and Methods}

\subsection{Synthesis}

Infrared spectra were recorded on (FTIR-8400s Fouriero Trans Form Infrared Spectrophotometer Shimadzu). UV Spectra were recorded on UVVisible spectrophotometer (VARIAN) UV-1650PC. ${ }^{1} \mathrm{H}-\mathrm{NMR}$ spectra (Burker DMX -500 NMR spectrophotometer) were recorded on ultra shield 300 MHZ in Jordan, with tetra methyl silane as internal standerd and DMSO as a solvent. Melting points were determined in a (Gallen kamp MFB-600Melting point apparatus) melting point apparatus with sample contained in open capillary glass tube in an electrically heated metal block apparatus, and were uncorrected. All chemicalls were supplied from $\mathrm{BDH}$, Merck, Fluka and used without further purification.

2.1.1. Synthesis of chloro-1-benzothiophene2-carbonyl chloride $(\mathrm{C1})$

Cinnamic acid (29.63g, $0.20 \mathrm{~mol})$, chlorobenzene $(150 \mathrm{ml})$, and $\mathrm{SOCl}_{2}(119 \mathrm{~g}, 1 \mathrm{~mol})$ was stirred at room temperature for $30 \mathrm{~min}$. then, pyridine (1.58 g, $0.02 \mathrm{~mol}$ ) was carefully added and the reaction mixture was refluxed for $72 \mathrm{~h}$. The resulting residue was suspended in hot cyclohexane $(400 \mathrm{ml})$ and immediately filtered. Upon staying at room temperature overnight, the title compound $(\mathrm{C} 1)$ crystallized as yellow needles.
2.1.2.
Synthesis
of 3 -

chlorobenzo[b]thiophene-2-carbohydrazide(C2)

A mixture of compound $(\mathrm{C} 1)(2.29 \mathrm{~g}, 0.01 \mathrm{~mol})$ and hydrazine hydrate $(99 \%, 0.32 \mathrm{~g}, 0.01 \mathrm{~mole})$ in benzene $(25 \mathrm{~mL})$ was refluxed for $4 \mathrm{~h}$. Upon cooling the solution, a solid appeared. This was recrystallized from ethanol to afford the desired compound(C2).

2.1.3. Synthesis of 3-chloro-N'-(Arylidene) benzo [b] thiophene-2 carbohydrazide $(\mathrm{C3})$

Aryl aldehyde $(0.01 \mathrm{~mol})$ was added to a stirred solution of compound (C2) $(2.27 \mathrm{~g}, 0.01 \mathrm{~mol})$ in absolute ethanol $(30 \mathrm{ml})$ and the mixture was refluxed for $8 \mathrm{~h}$. After cooling, the mixture was filtered and the solid recrystallized from ethanol to afford the desired compound(C3).

2.1.4. Synthesis of N-(2-(Aryl)-4-oxo-3phenylazetidin-1-yl)-3-chlorobenzo[b]thiophe- ne -2-carboxamide(C4)

To a mixture of phenylacetic acid (1.35 g, $0.01 \mathrm{~mol})$, imine $(\mathrm{C} 3)(0.01 \mathrm{~mol})$ and triethylamine $(4.04 \mathrm{~g}, 0.01 \mathrm{~mol})$ in dry dichloromethane $(40 \mathrm{ml})$ at $0^{\circ} \mathrm{C}$, a solution of $\mathrm{SOCl}_{2} \quad(15 \mathrm{ml})$ in dry dichloromethane $(20 \mathrm{ml})$ was added as drop wise . The mixture was stirred $24 \mathrm{~h}$ at room temperature. Then the mixture was washed successively with $1 \mathrm{~N}$ $\mathrm{HCl}(30 \mathrm{ml})$, water $(3 \times 30 \mathrm{ml})$, and $5 \% \quad \mathrm{NaHCO}_{3}$ $(30 \mathrm{ml})$. The organic layer was separated and dried over anhydrous sodium sulphate $\left(\mathrm{Na}_{2} \mathrm{SO}_{4}\right)$, and then filtered solvent was removed under reduce pressure. The solid recrystallized from DMSO: $\mathrm{H}_{2} \mathrm{O}$ to afford the desired compound. The physical properties are listed in Table (1).

Physical properties of compounds (C1 - C4).

Table (1)

\begin{tabular}{|c|c|c|c|c|}
\hline $\begin{array}{c}\text { Comp. } \\
\text { No }\end{array}$ & Colour & $\begin{array}{c}\text { Yield } \\
\%\end{array}$ & M.P \\
\hline $\mathrm{Cl}$ & & Yellow & 73 & $111-113$ \\
\hline
\end{tabular}




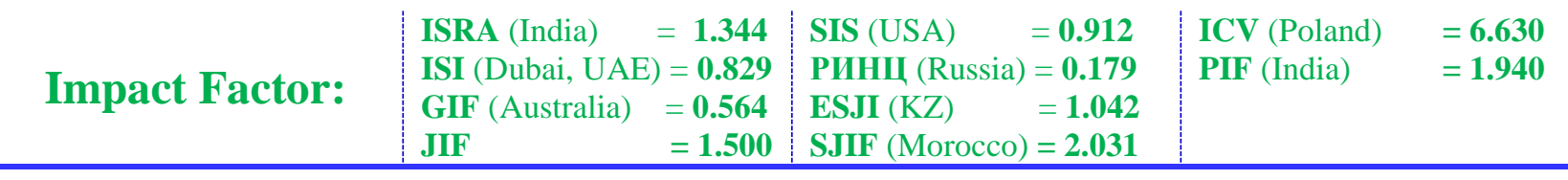

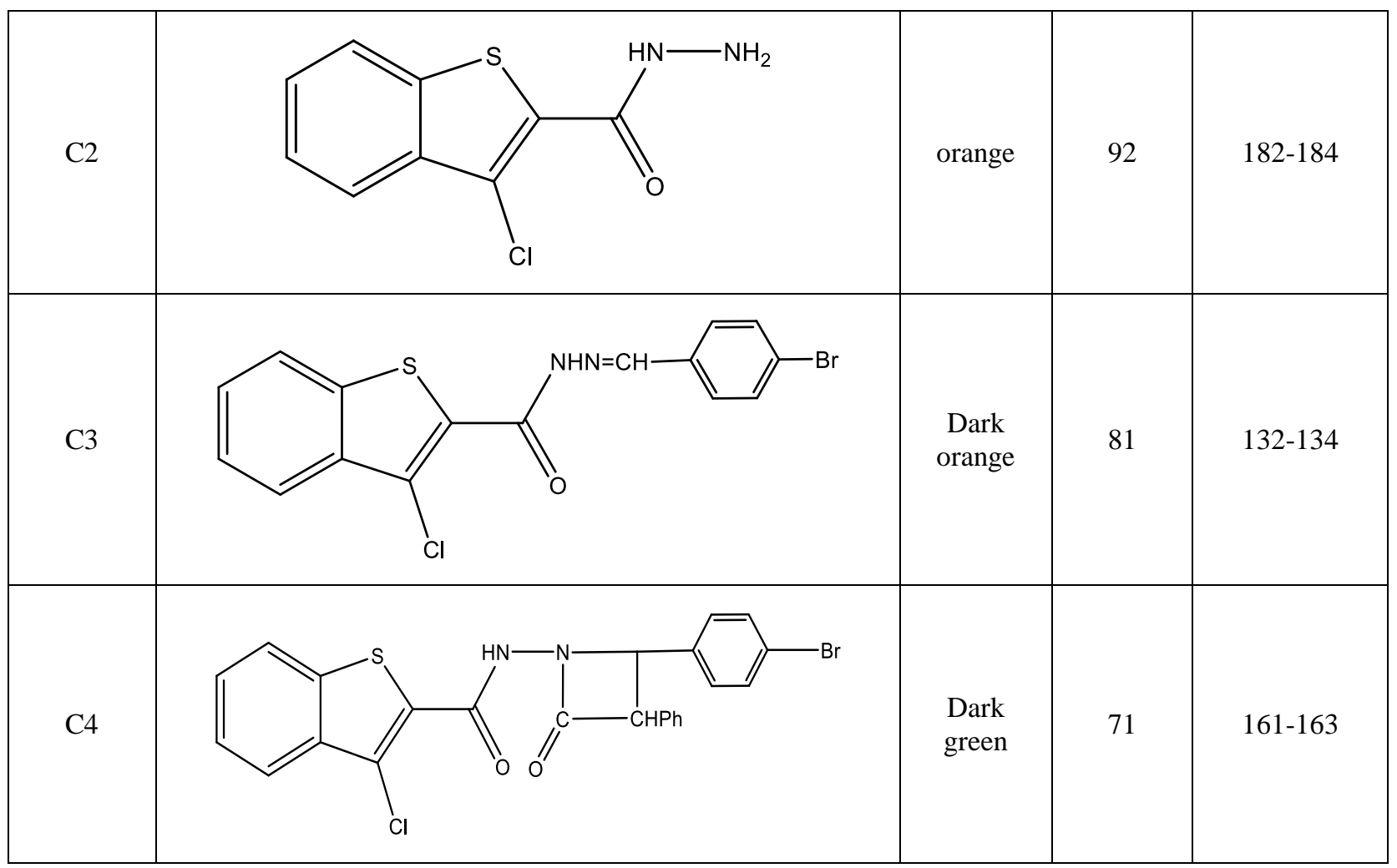

Synthesis of 2-(3-chlorobenzo[b]thiophene-2carboxamido) acetic acid(C5)

Compound (C1) $(2.29 \mathrm{~g}, 0.01 \mathrm{~mol})$ was added to a stirring solution of L-glycine $(0.75 \mathrm{~g}, 0.01 \mathrm{~mol})$ and sodium hydroxide ( $50 \mathrm{ml}, 10 \%$ solution). Then, the reaction mixture was shaken vigorously for $1 \mathrm{~h}$, and a few grams of crushed ice were added with stirring. After that, the solution was acidified with conc. $\mathrm{HCl}$ and the product was collected and recrystallized from ethanol.
2.1.6.
Synthesis
of
2-(3-

chlorobenzo[b]thiophen-2-yl)-4-(Arylidene)

oxazol-5(4H)-one(C6)

Aromatic aldehyde $(0.01 \mathrm{~mol})$ was added to a stirring mixture of compound (C5) (2.69 g, 0.01 mol), acetic acid $(5 \mathrm{ml})$ and acetic anhydride $(20 \mathrm{ml})$. The temperature of reaction was increased to $70{ }^{\circ} \mathrm{C}$ for $10 \mathrm{~min}$., then the mixture was poured into crushed ice and stirred for $30 \mathrm{~min}$. the product was collected and recrystallized from ethanol to afforded the desired compound.

2.1.7. Synthesis of 1-amino-2-(3chlorobenzo[b]thiophen-2-yl)-4-(Arylidene)-1Himidazol-5(4H)-one $(\mathrm{C} 7)$

Hydrazine hydrate $(99 \%, 10 \mathrm{ml})$ was added to a mixture of compound (C6) (0.01 mol) in dry benzene $(5 \mathrm{ml})$. The reaction mixture was refluxed for $20 \mathrm{~h}$ after cooling the solid product was obtaining and recrystallized from ethanol. The physical properties are listed in Table (2).

Physical properties of compounds (C5 - C7).

Table (2)

\begin{tabular}{|c|c|c|c|c|}
\hline $\begin{array}{c}\text { Comp. } \\
\text { No }\end{array}$ & Compound structure & Colour & $\begin{array}{c}\text { Yield } \\
\%\end{array}$ & M.P \\
\hline Cl 5 & brown & & \\
\hline
\end{tabular}




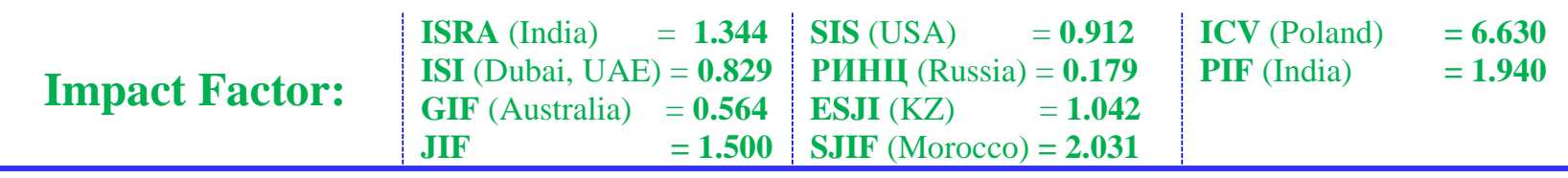

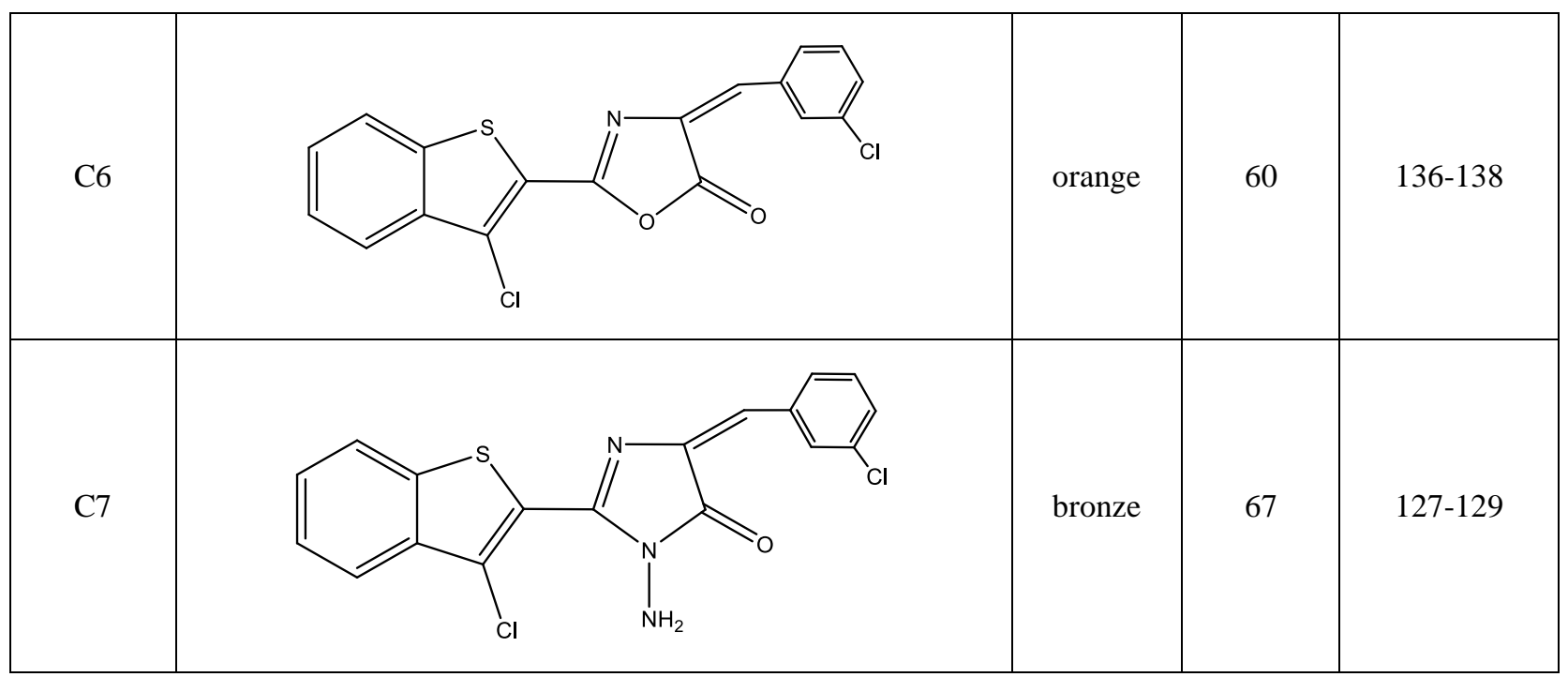

\section{Vitro:}

\subsection{Determination of antifungal activity In}

These compounds of derivatives $(\mathrm{C} 4, \mathrm{C} 7)$ was assayed for antifungal activity against $T$. mentagrophytes by using Potato Dextrose Agar (PDA) plate. A fungal plug (5 $\mathrm{mm}$ diameter) was removed from the 5 day old culture. The plug was transferred onto the center of the PDA plate, which had been loaded with different concentration of compound $(\mathrm{C} 4, \mathrm{C} 7)$ derivatives compounds (1000, $10000) \mu \mathrm{g} / \mathrm{ml}$. The plate was incubated for 5-7 days at $30^{\circ} \mathrm{C}$ and was monitored for a colony diameter in $\mathrm{mm}$, and compare with control [22].

\subsection{Measurement LD50 for compound (C4)}

Five groups of 6 mice (4weeks old), weighting approximately $20 \mathrm{gm}$,from National Center For Drug Control and Research (NCDCR), were injected intra peritoneal with $0.5 \mathrm{ml}$ of $(\mathrm{C} 4)$ and from each concentration from the stock $(500,1000$, $5000,10000) \mu \mathrm{g} / \mathrm{ml}$, two mices were injected with $0.5 \mathrm{ml}$ normal saline and two mices were injected with $0.5 \mathrm{ml}$ DMSO as a control .After $24 \mathrm{hr}$, all mices( which injected) were examined and determined the concentration which was killed half of animals and consider $\mathrm{LD}_{50}[23]$.

\subsection{Determination of antifungal activity in} vivo:

Skin infection in Rabbit with Trichophyton mentagrophytes fungus was done by contaminated the skin by fungus suspension and the infection was monitoring and show the scale in skin and hair. compounds (C4) was assayed for antifungal activity against Trichophyton mentagrophytes in vivo for treatment the skin infection in Rabbit with $500 \mu \mathrm{g} / \mathrm{ml}$ 13 time daily for one week, Vaseline was used as ointment in the control group.

\section{Results and Discussion}

\subsection{Synthesis}

T. mentagrophytes, representing the complex, is a highly keratinolytic fungus. It secretes a variety of proteases which enable it to attack different karatinous substrates. It is a non-fastidious fungus.

For the synthesis of the targeted compounds (C1- C4), the reaction sequences are outlined in scheme (1): 


\begin{tabular}{l|lrl|l|ll} 
& ISRA (India) & $=\mathbf{1 . 3 4 4}$ & SIS (USA) & $=\mathbf{0 . 9 1 2}$ & ICV (Poland) & $=\mathbf{6 . 6 3 0}$ \\
Impact Factor: & ISI (Dubai, UAE) $=\mathbf{0 . 8 2 9}$ & PUHU (Russia) $=\mathbf{0 . 1 7 9}$ & PIF (India) & $=\mathbf{1 . 9 4 0}$ \\
& GIF (Australia) & $\mathbf{0 . 5 6 4}$ & ESJI (KZ) & $=\mathbf{1 . 0 4 2}$ & & \\
& JIF & $=1.500$ & SJIF (Morocco) & $=\mathbf{2 . 0 3 1}$ & &
\end{tabular}

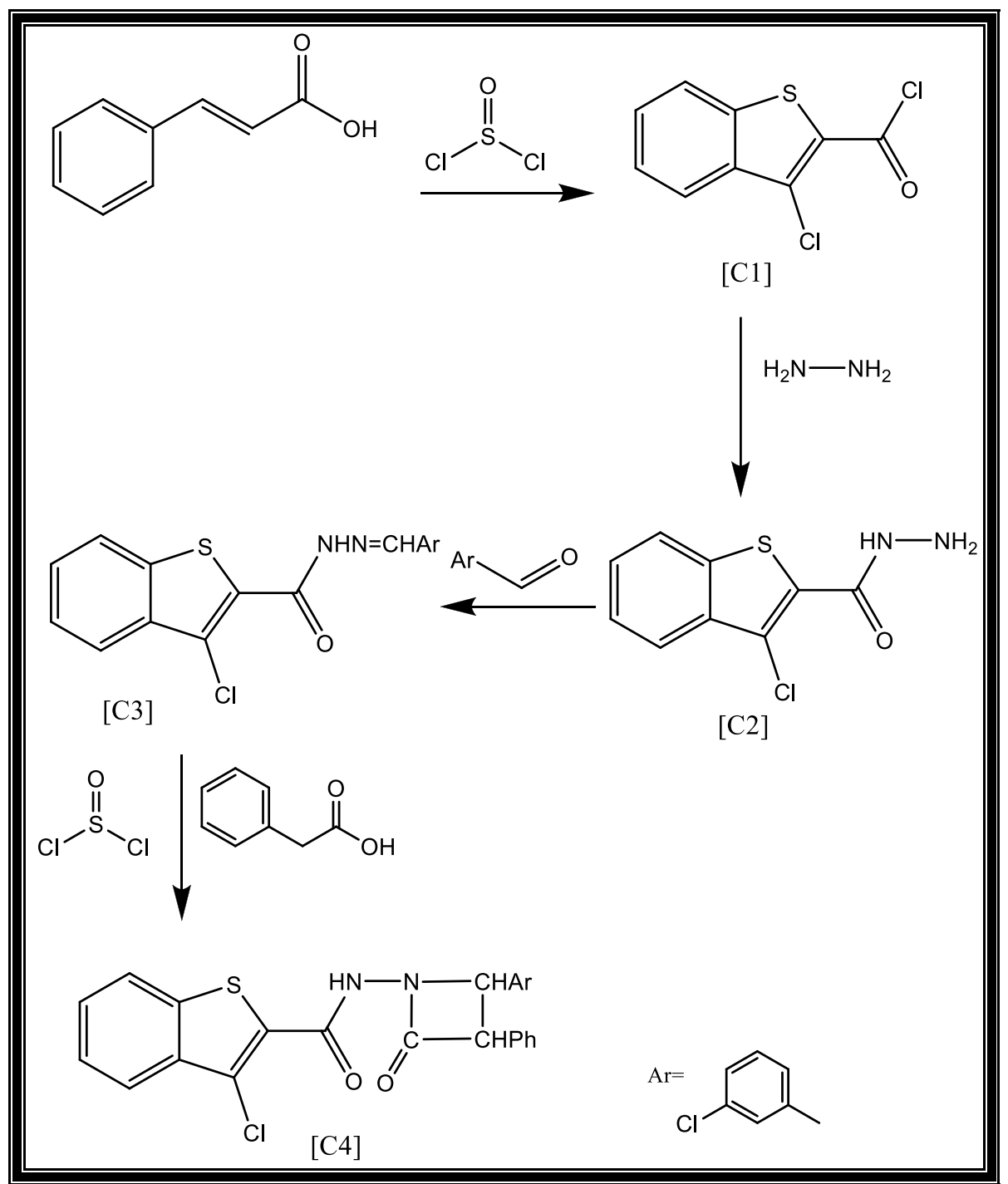

Scheme (1): Synthesis $\beta$-lactam derivatives.

Synthesis of3-Chlorobenzo[b]thiophene-2carbonyl chloride (C1)

For synthesis of the target compounds (C1) which was prepared by the reaction of cinnamic acid and thionyl chloride. The structure of compound was confirmed by FT-IR and U.V spectrum. The FT-IR spectrum of compound (C1) (Fig. 1) shows disappearing of stretching vibration of $(\mathrm{OH})$ group of carboxylic acid at (2500-3300) $\mathrm{cm}^{-1}$ and increasing frequency of $(\mathrm{C}=\mathrm{O})$ to $(1763) \mathrm{cm}^{-1}$, also spectrum shows anther bands, (3059) $\mathrm{cm}^{-1}$ for aromatic $(\mathrm{C}-\mathrm{H})$, band at $(1597,1479) \mathrm{cm}^{-1}$ due to aromatic $(\mathrm{C}=\mathrm{C})$, bands at (700) $\mathrm{cm}^{-1}$ for stretching vibration of (C-SC)group and bands at(758) $\mathrm{cm}^{-1}$ for stretching vibration of (C-Cl)group. U.V. spectrum showed two absorption $\lambda_{\max }$ at $232 \mathrm{~nm}\left(\pi-\pi^{*}\right)$ and $344 \mathrm{~nm}\left(\mathrm{n}-\pi^{*}\right)$ electronic transition. 


\begin{tabular}{l|lrl|l|ll} 
& ISRA (India) & $=\mathbf{1 . 3 4 4}$ & SIS (USA) & $=\mathbf{0 . 9 1 2}$ & ICV (Poland) & $=\mathbf{6 . 6 3 0}$ \\
Impact Factor: & ISI (Dubai, UAE) $=\mathbf{0 . 8 2 9}$ & PUHU (Russia) $=\mathbf{0 . 1 7 9}$ & PIF (India) & $=\mathbf{1 . 9 4 0}$ \\
& GIF (Australia) & $\mathbf{0 . 5 6 4}$ & ESJI (KZ) & $=\mathbf{1 . 0 4 2}$ & & \\
& JIF & $=1.500$ & SJIF (Morocco) & $=\mathbf{2 . 0 3 1}$ & &
\end{tabular}

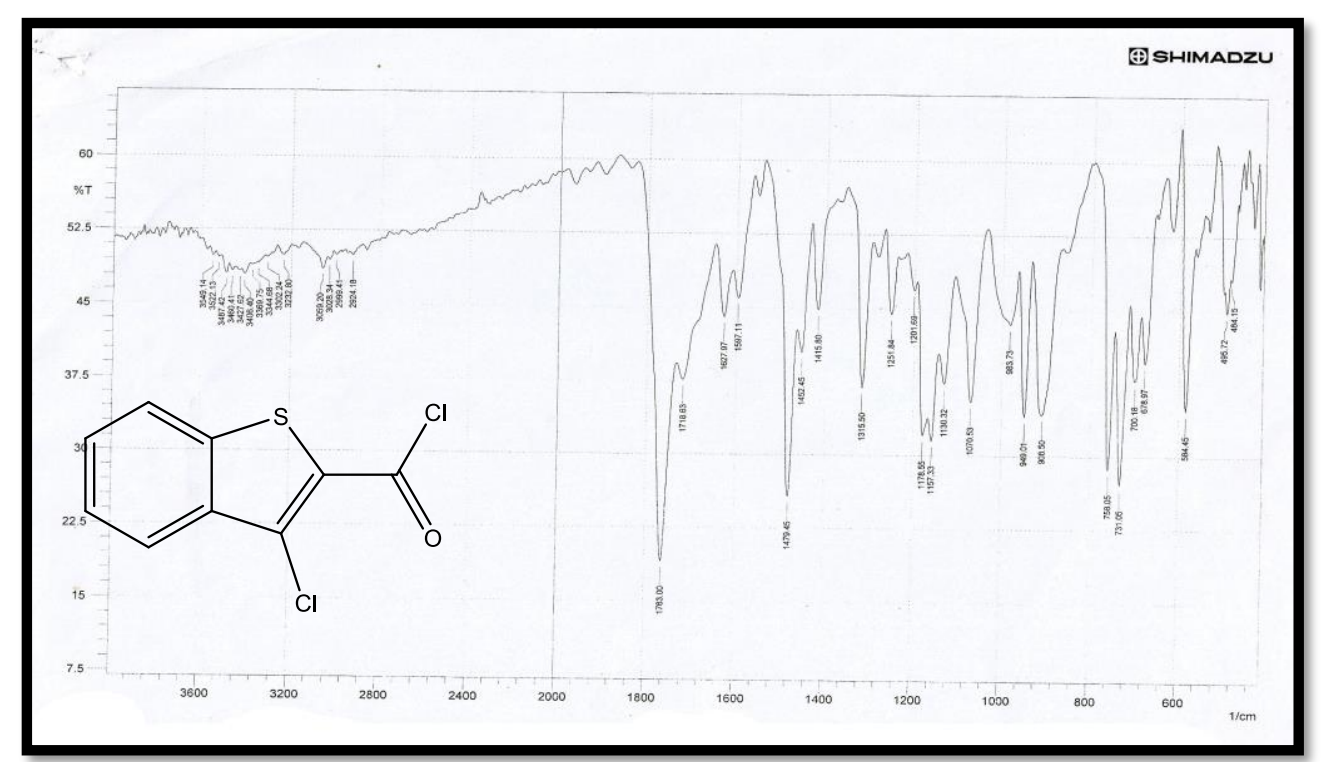

Fig. 1: The FT-IR spectrum of compound (C1).

Synthesis of 3-chlorobenzo[b]thiophene-2carbohydrazide(C2)

This compound was obtained by the reaction of 3-Chlorobenzo [b]thiophene-2-carbonyl chloride(C1) with hydrazine hydrate. The structure of compound (C2) was confirmed by FT-IR, U.V and ${ }^{1}$ HNMR spectrum. FT-IR spectrum of compound (C2) (fig.2) shows the following bands, two bands at (33173286) $\mathrm{cm}^{-1}$ due to stretching vibration (asymmetric and symmetric) for $\left(\mathrm{NH}_{2}\right)$ group, band at $(3200) \mathrm{cm}^{-1}$ due to stretching vibration of $(\mathrm{NH})$, decrease stretching vibration of carbonyl group to (1653) $\mathrm{cm}^{-1}$.
UV spectrum of compound (C2) shows intense maxima at $(268 \mathrm{~nm})$ and $(328 \mathrm{~nm})$ due to $\pi \rightarrow \pi^{*}$ and $\mathrm{n} \rightarrow \pi^{*}$ electronic transition, respectively. The ${ }^{1} \mathrm{H}-$ NMR of compound (C2) (Fig. 3), shows the following signals:

- Singlet at (12.40) ppm due to one (NH) group proton.

- Multiplet at (7.60-8.10) ppm due to four aromatic protons.

- Singlet at (4.72) ppm due to tow $\left(\mathrm{NH}_{2}\right)$ group proton.

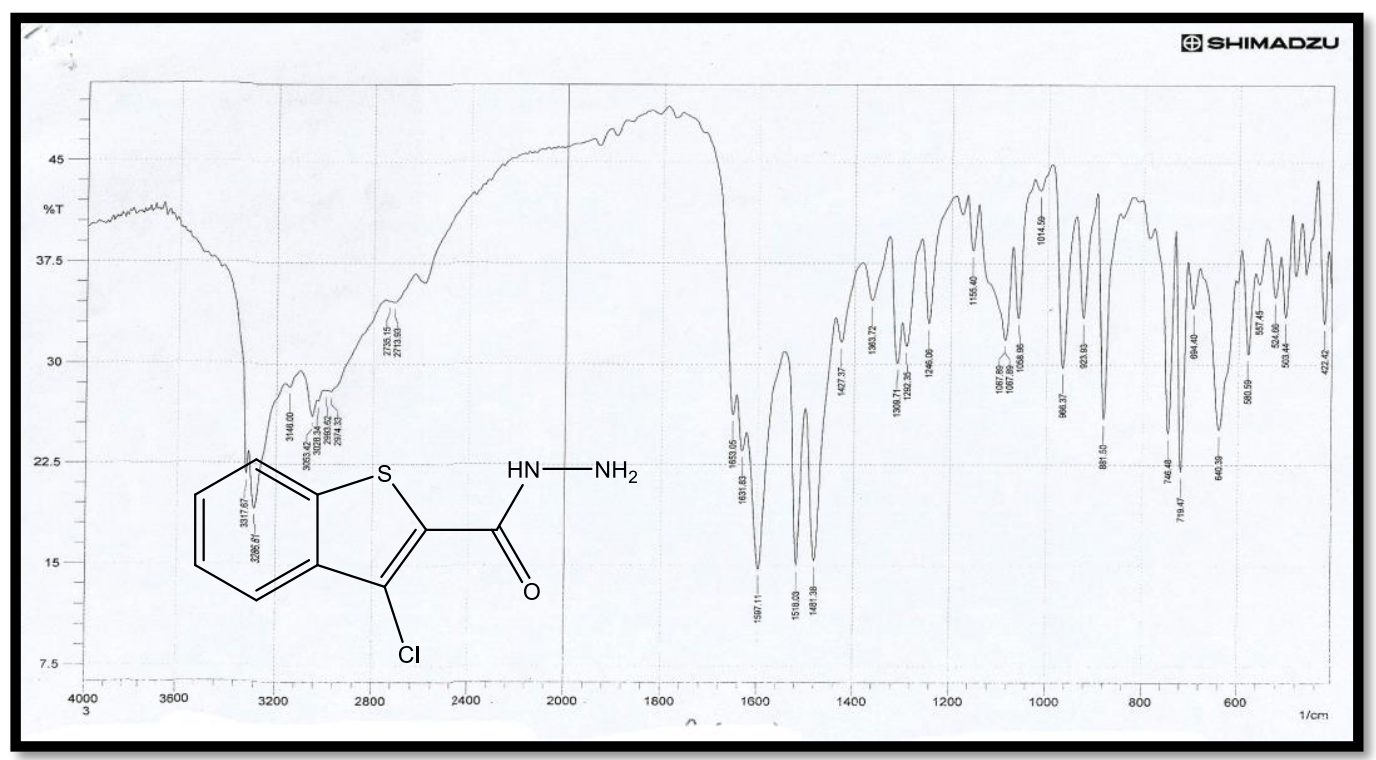

Fig. 2: The FT-IR spectrum of compound (C2). 


\begin{tabular}{l|lrl|l|ll} 
& ISRA (India) & $=\mathbf{1 . 3 4 4}$ & SIS (USA) & $=\mathbf{0 . 9 1 2}$ & ICV (Poland) & $=\mathbf{6 . 6 3 0}$ \\
Impact Factor: & ISI (Dubai, UAE) $=\mathbf{0 . 8 2 9}$ & PUHU (Russia) $=\mathbf{0 . 1 7 9}$ & PIF (India) & $=\mathbf{1 . 9 4 0}$ \\
& GIF (Australia) & $\mathbf{0 . 5 6 4}$ & ESJI (KZ) & $=\mathbf{1 . 0 4 2}$ & & \\
& JIF & $=\mathbf{1 . 5 0 0}$ & SJIF (Morocco) $=\mathbf{2 . 0 3 1}$ & &
\end{tabular}

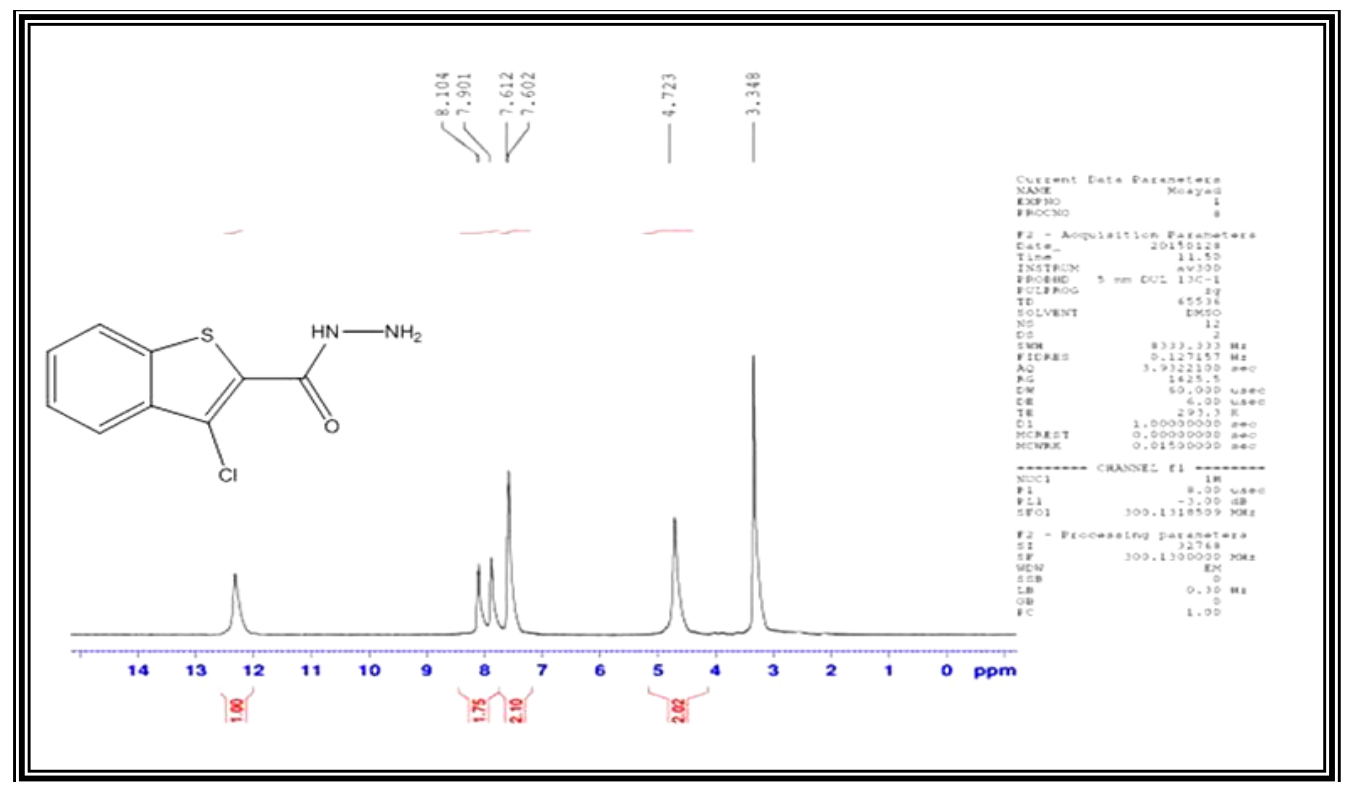

Fig. 3: The ${ }^{1} \mathrm{H}-\mathrm{NMR}$ spectrum of compound (C2).

Synthesis of 3-chloro-N'-(Arylidene) benzo[b]thiophene-2-carbohydrazide (C3)

Compound (C2) undergoes the character condensation reaction with aromatic aldehyde in absolute ethanol to give the Schiff- base (C3). The formation of these Schiff's base was indicated by the disappearance of the $\mathrm{NH}_{2}$ stretching vibration band. The structure of compound (C3) was confirmed by
FT-IR and U.V spectrum. FT-IR spectrum (fig 4) of compound (C3), shows the following bands, band at (3215) $\mathrm{cm}^{-1}$ due to stretching vibration of $(\mathrm{NH})$ group, and band at $(1620) \mathrm{cm}^{-1}$ for stretching vibration of $(\mathrm{C}=\mathrm{N})$ group. $\mathrm{UV}$ spectrum of compound (C3) shows intense maxima at $(248 \mathrm{~nm})$ and $(335 \mathrm{~nm})$ due to $\pi \rightarrow \pi^{*}$ and $\mathrm{n} \rightarrow \pi^{*}$ electronic transition, respectively.

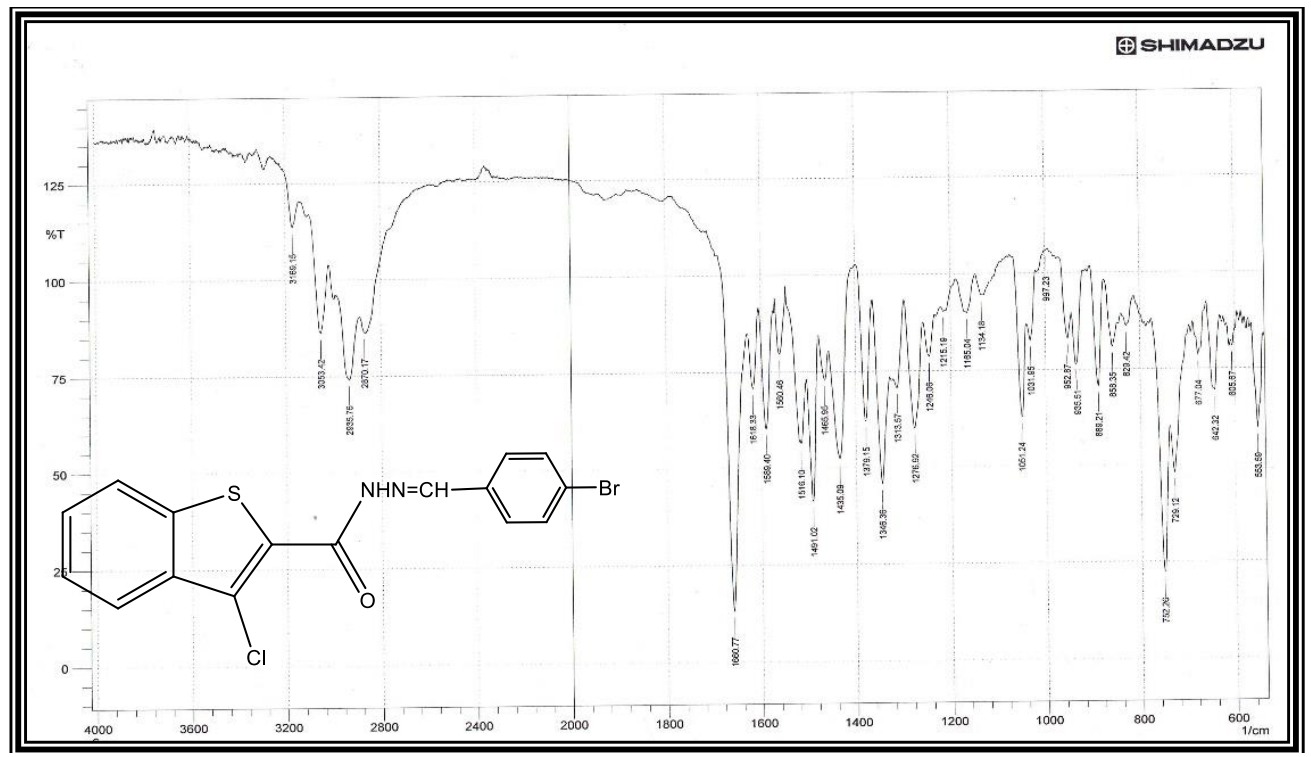

Fig. 4: The FT-IR spectrum of compound (C3).

Synthesis ofN-(Aryl)-4-oxo-3-phenylazetidin1-yl)-3-chlorobenzo[b]thiophene-2-carboxamide (C4)

Synthesis of $\beta$-lactam was done by treating a phenylacetic acid with triethylamine to form anione which then producing cycloaddition reaction with
(C3) in the presence of $\mathrm{SOCl}_{2}$ to form the appropriate $\beta$-lactam (C4). The formation of these $\beta$ lactams was indicated by the appearance of the two stretching vibration bands $(1722,1701) \mathrm{cm}^{-1}$ to carbonyl group .The structure (C4) was confirmed by FT-IR ,U.V and ${ }^{1}$ HNMR spectrum. FT-IR spectra 


\begin{tabular}{|c|c|c|c|c|c|c|}
\hline Impact Factor: & $\begin{array}{l}\text { ISRA (India) } \\
\text { ISI (Dubai, UAF } \\
\text { GIF (Australia) } \\
\text { JIF }\end{array}$ & $\begin{array}{l}=1.344 \\
=0.829 \\
=0.564 \\
=1.500\end{array}$ & $\begin{array}{l}\text { SIS (USA) } \\
\text { PИНЦ (Russia } \\
\text { ESJI (KZ) } \\
\text { SJIF (Moroccc }\end{array}$ & $\begin{array}{l}=0.912 \\
=0.179 \\
=1.042 \\
=2.031\end{array}$ & $\begin{array}{l}\text { ICV (Poland) } \\
\text { PIF (India) }\end{array}$ & $\begin{array}{l}=6.630 \\
=1.940\end{array}$ \\
\hline
\end{tabular}

(fig 5) , Table (3) shows the stretching vibration bands at (3201) $\mathrm{cm}^{-1}$ due to $(\mathrm{NH})$ group , band at(3061) $\mathrm{cm}^{-1}$ due to aromatic $(\mathrm{C}-\mathrm{H})$, band at $(2982,2890) \mathrm{cm}^{-1}$ aliphatic $(\mathrm{CH})$, band at $(1722,1701)$ $\mathrm{cm}^{-1}$ for $(\mathrm{C}=\mathrm{O})$ group and band at $(1591,1512) \mathrm{cm}^{-1}$ for aromatic $(\mathrm{C}=\mathrm{C})$. UV spectrum of compound $(\mathrm{C} 4)$ shows intense maxima at $(276 \mathrm{~nm})$ and $(358 \mathrm{~nm})$ due to $\pi \rightarrow \pi^{*}$ and $\mathrm{n} \rightarrow \pi^{*}$ electronic transition, respectively.

The ${ }^{1} \mathrm{H}-\mathrm{NMR}$ of compound (C4) (Fig. 6), shows the following signals:

- Singlet at (12.5) ppm due to ( $\mathrm{NH}$ ) group proton.
Doublet at (8.01-8.16) ppm due to two aromatic proton.

- Multiplet at (7.87-7.94) ppm due to four proton of aromatic ring of benzothiophen.

- Multiplet at (7.47-7.72) ppm due to five proton of phenyl ring .

- Doublet, Doublet at (7.38-7.40) ppm due to two aromatic proton.

- Doublet at (5.60-5.62) ppm due to ( $\mathrm{CHCO}$ ) group proton.

- Doublet at (4.46-4.47)ppm due to ( $\mathrm{CH}-\mathrm{N}$ ) group proton.

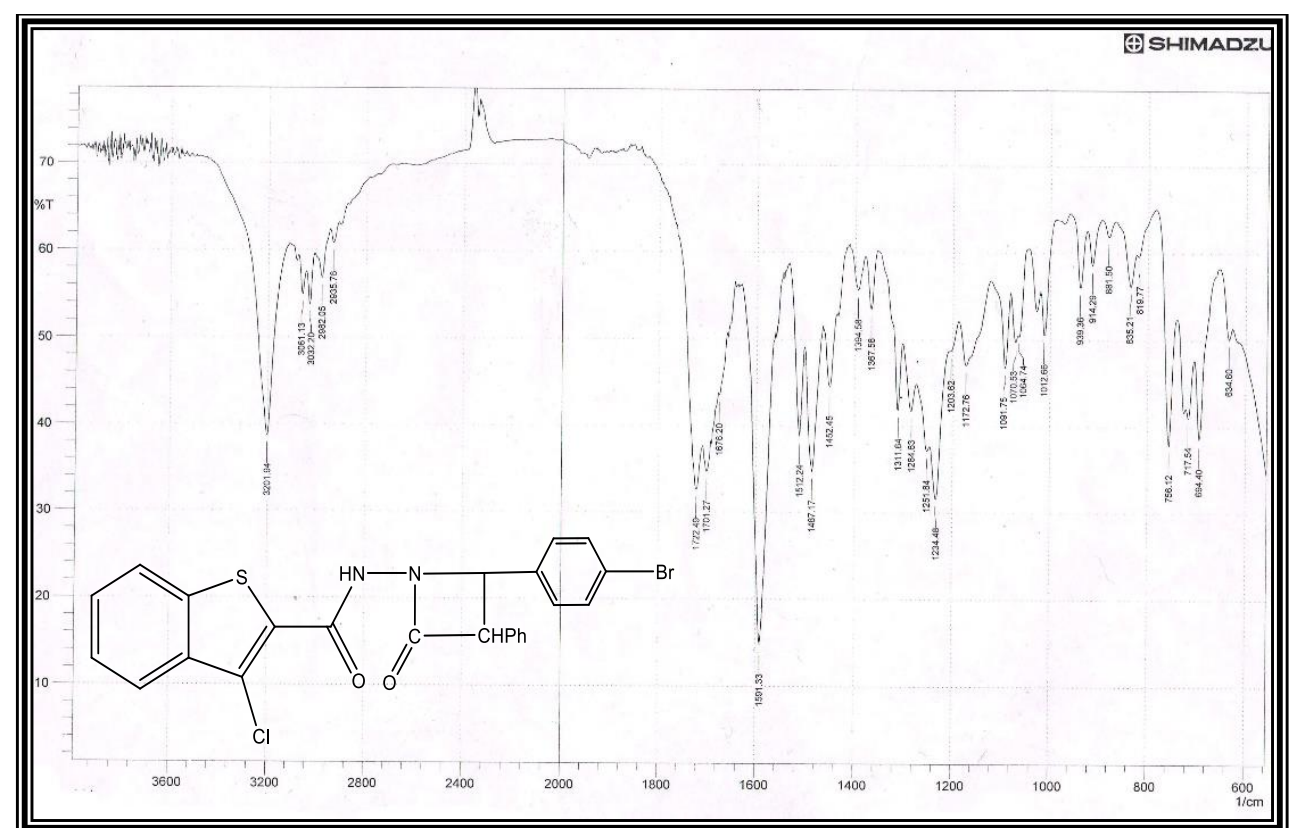

Fig. 5: The FT-IR spectrum of compound (C4)

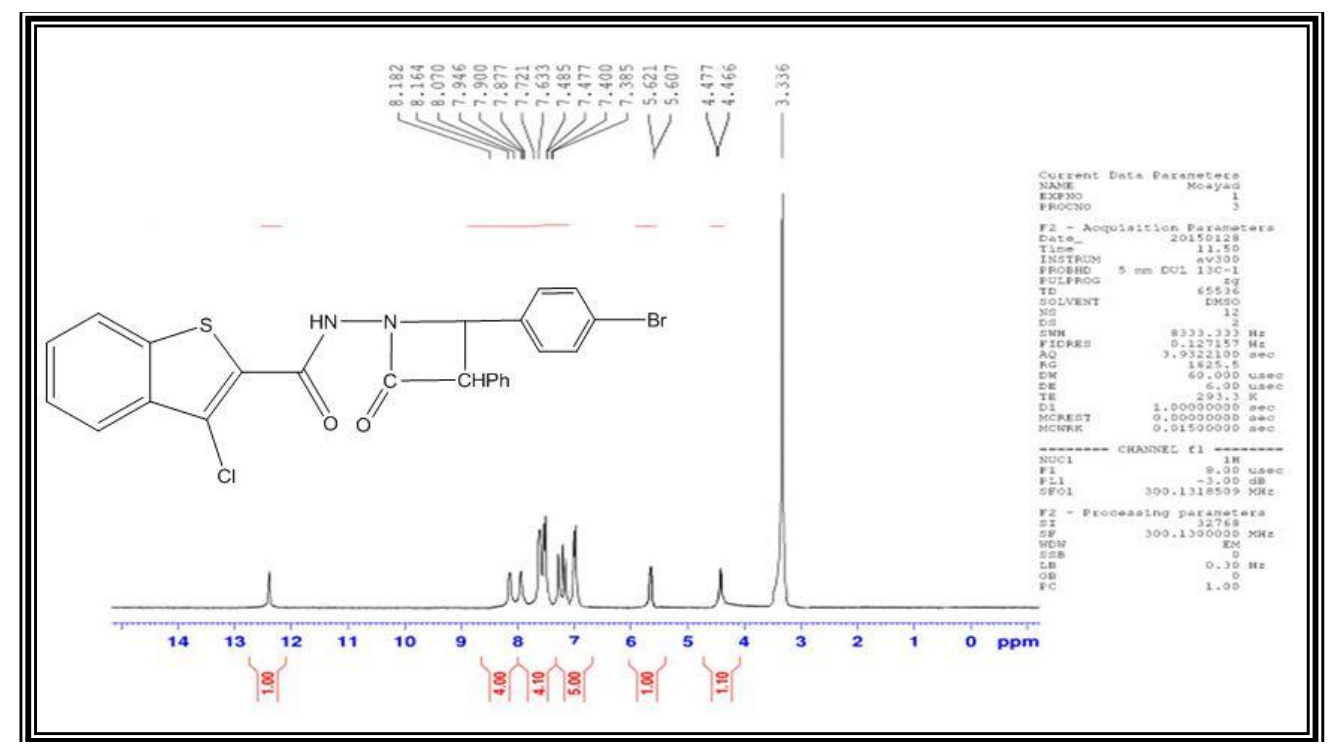

Fig. 6: The ${ }^{1} \mathrm{H}-\mathrm{NMR}$ spectrum of compound $(\mathrm{C} 4)$ 


\begin{tabular}{l|lrl|l|ll} 
& ISRA (India) & $=\mathbf{1 . 3 4 4}$ & SIS (USA) & $=\mathbf{0 . 9 1 2}$ & ICV (Poland) & $=\mathbf{6 . 6 3 0}$ \\
Impact Factor: & ISI (Dubai, UAE) $=\mathbf{0 . 8 2 9}$ & PUHU (Russia) $=\mathbf{0 . 1 7 9}$ & PIF (India) & $=\mathbf{1 . 9 4 0}$ \\
& GIF (Australia) & $\mathbf{0 . 5 6 4}$ & ESJI (KZ) & $=\mathbf{1 . 0 4 2}$ & & \\
& JIF & $=\mathbf{1 . 5 0 0}$ & SJIF (Morocco) $=\mathbf{2 . 0 3 1}$ & &
\end{tabular}

IR spectral data for compounds (C1 - C4).

Table (3)

\begin{tabular}{|c|c|c|c|c|c|c|}
\hline \multirow{2}{*}{$\begin{array}{c}\text { Comp. } \\
\text { No }\end{array}$} & \multicolumn{6}{|c|}{ Characteristic IR bands v(cm $\left.{ }^{-1}\right)$} \\
\hline C1 & $\mathrm{NH}$ & $\begin{array}{c}\mathrm{CH} \\
\text { aromatic }\end{array}$ & $\mathrm{C}=\mathrm{O}$ & $\mathrm{C}=\mathrm{N}$ & $\begin{array}{c}\mathrm{C}=\mathrm{C} \\
\text { aromatic }\end{array}$ & other \\
\hline $\mathrm{C} 2$ & 3200 & 3053 & 1653 & & 1597,1479 & $\begin{array}{c}3317,3286 \\
\mathrm{NH}\end{array}$ \\
\hline $\mathrm{C} 3$ & 3215 & 3051 & 1643 & 1620 & 1589,1546 & $\begin{array}{c}3191(\mathrm{~N}=\mathrm{CH}), 637(\mathrm{C}- \\
\mathrm{Br})\end{array}$ \\
\hline $\mathrm{C} 4$ & 3201 & 3061 & 1722,1701 & & 1591,1512 & $628(\mathrm{C}-\mathrm{Br})$ \\
\hline
\end{tabular}

For the synthesis of the targeted compounds (C5- C7), the reaction sequences are outlined in scheme (2):

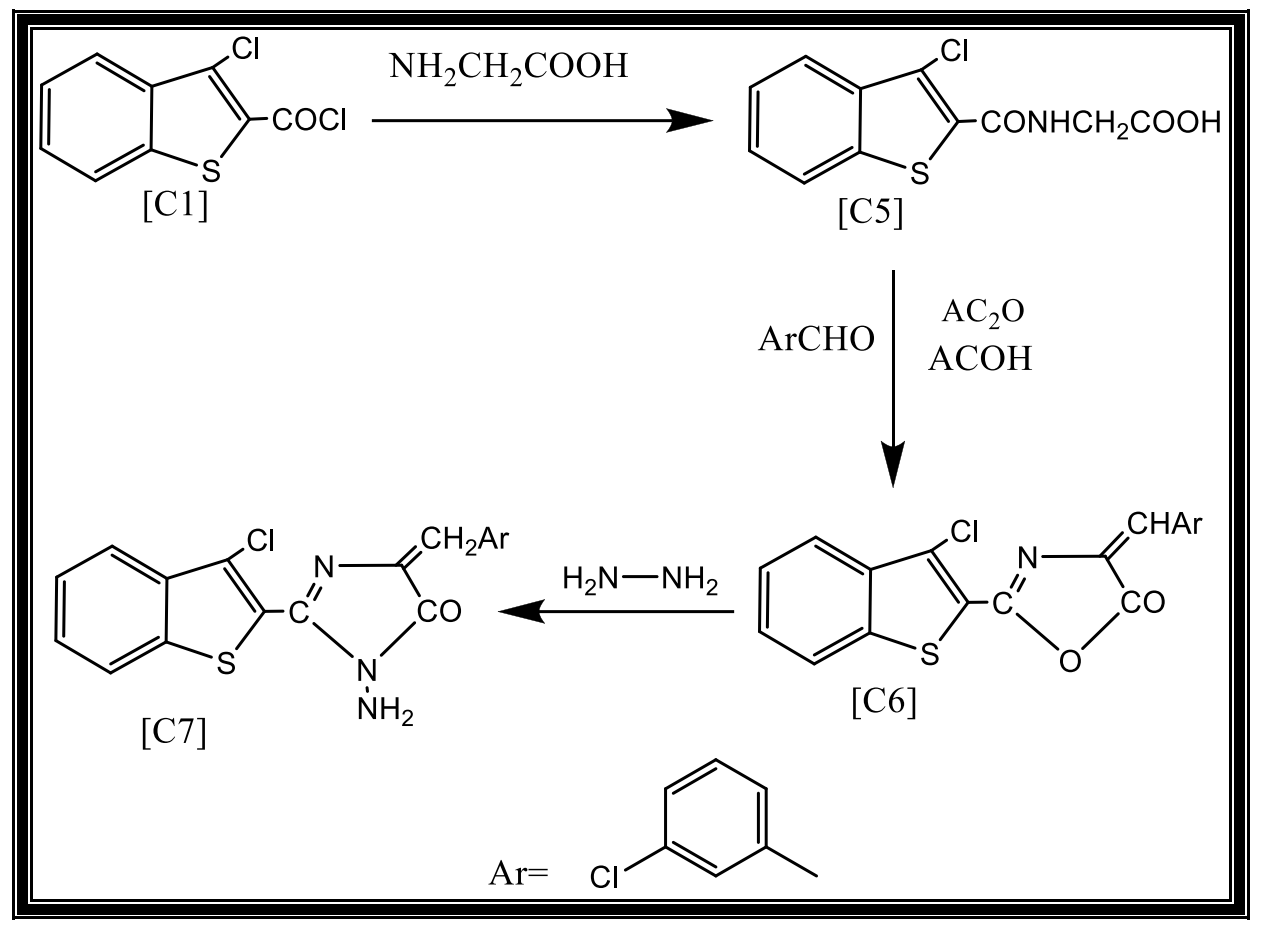

Scheme (2) : Synthesis Imidazole derivatives.

Synthesis of 2-(3-chlorobenzo[b]thiophene-2carboxamido)acetic acid (C5)

This compound was synthesized by the reaction of compound (C1)with glycine in sodium hydroxide solution. The formation of (C5) was indicated by the appearance of the two stretching vibration bands to carbonyl group and the appearance of the two stretching vibration bands to $\mathrm{NH}, \mathrm{OH}$ group . The structure (C5) was confirmed by FT-IR, U.V and ${ }^{1}$ HNMR spectrum . FT-IR spectrum (fig .7) shows the stretching vibration bands at $(3390) \mathrm{cm}^{-1}$ due to (NH) group, (3200-2500) $\mathrm{cm}^{-1}$ broad band for $(\mathrm{OH})$ group, band at $(3061) \mathrm{cm}^{-1}$ due to aromatic $(\mathrm{C}-\mathrm{H})$ ,band at $(2983,2939) \mathrm{cm}^{-1}$ due to aliphatic $(\mathrm{CH})$, band at $(1726,1685) \mathrm{cm}^{-1}$ due to $\operatorname{two}(\mathrm{C}=\mathrm{O})$ and band at $(1597,1533) \mathrm{cm}^{-1}$ due to for aromatic $(\mathrm{C}=\mathrm{C}) . \mathrm{UV}$ spectrum of compound (C5) shows intense maxima 


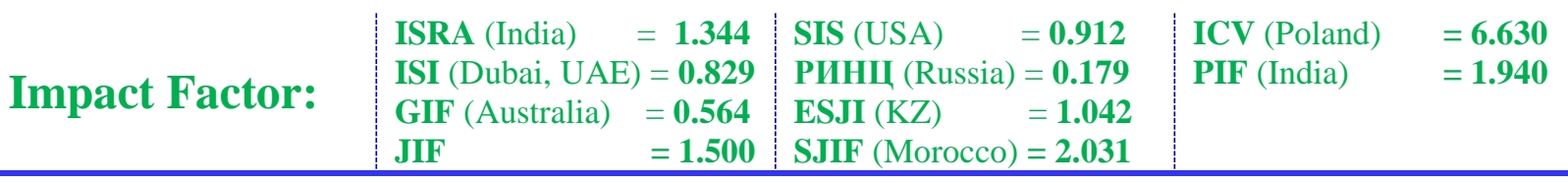

at $(257 \mathrm{~nm})$ and $(317 \mathrm{~nm})$ due to $\pi \rightarrow \pi^{*}$ and $\mathrm{n} \rightarrow \pi^{*}$ electronic transition, respectively .The ${ }^{1} \mathrm{H}-\mathrm{NMR}$ of compound (C5) (Fig. 8), shows the following signals:

- Singlet at (12.70) ppm due to to $(\mathrm{OH})$ group proton.
- Singlet at (9.65) ppm due to ( $\mathrm{NH}$ ) group proton.

- Multiplet at (7.47-8.11) ppm due to four aromatic protons.

- Singlet at (4.11) ppm due to two $\left(\mathrm{CH}_{2}\right)$ proton.

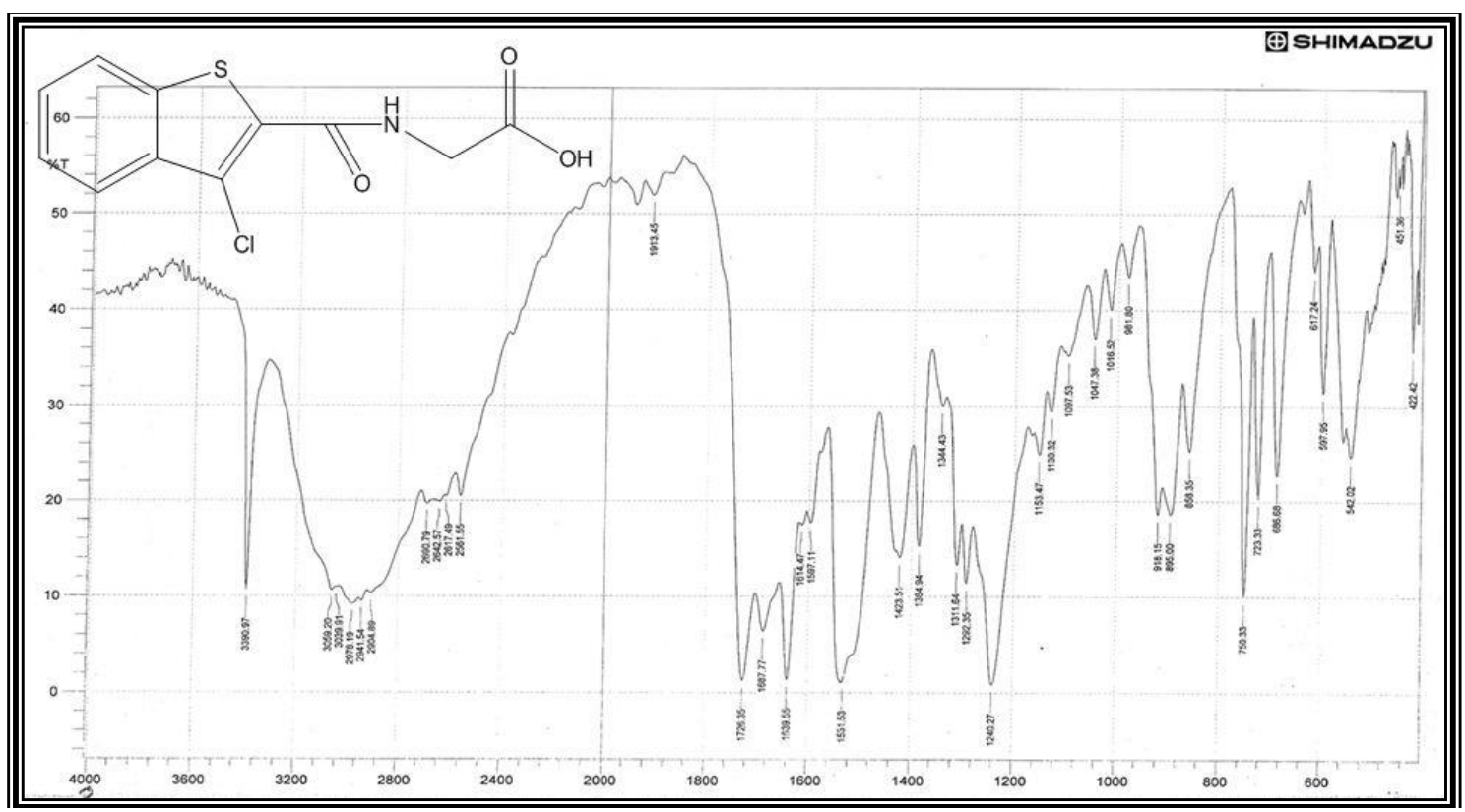

Fig. 7: The FT-IR spectrum of compound (C5).

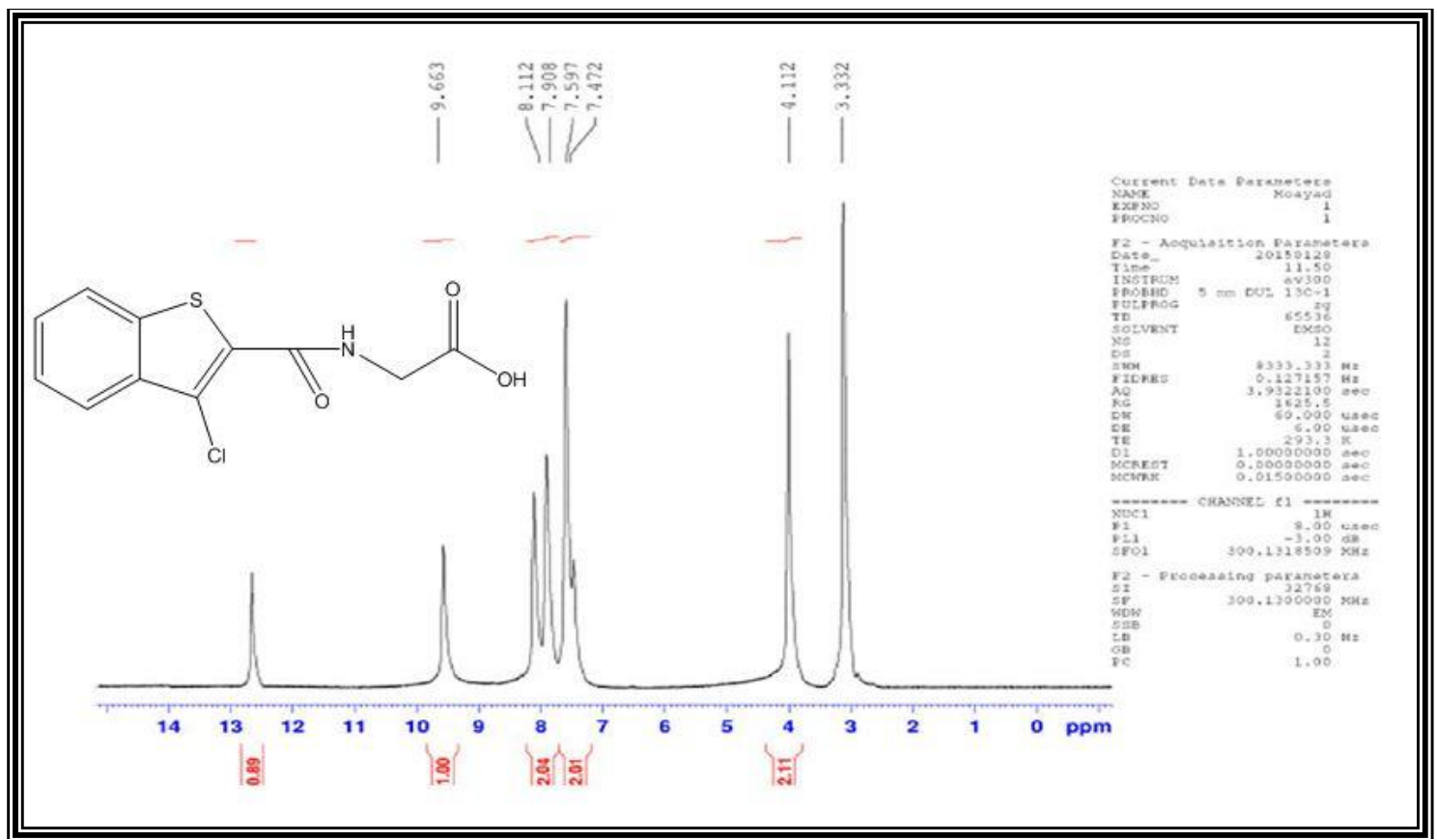

Fig. 8: The ${ }^{1} \mathrm{H}-\mathrm{NMR}$ spectrum of compound (C5).

Synthesis of 2-(3-chlorobenzo[b]thiophen-2yl)-4-(Arylidene)oxazol-5(4H)-one(C6)

This title compounds were synthesized according to the reaction of acid(C5) with aromatic aldehyde in acetic acid and acetic anhydride to give (C6). The formation of title compounds was indicated by the disappearance of the two stretching vibration bands to $\mathrm{NH}, \mathrm{OH}$ groups and appearance of 


\begin{tabular}{|c|c|c|c|c|c|c|}
\hline Impact Factor: & $\begin{array}{l}\text { ISRA (India) } \\
\text { ISI (Dubai, UAF } \\
\text { GIF (Australia) } \\
\text { JIF }\end{array}$ & $\begin{array}{l}=1.344 \\
=0.829 \\
=0.564 \\
=1.500\end{array}$ & $\begin{array}{l}\text { SIS (USA) } \\
\text { PИНЦ (Russia) } \\
\text { ESJI (KZ) } \\
\text { SJIF (Morocco) }\end{array}$ & $\begin{array}{l}=0.912 \\
=0.179 \\
=1.042 \\
=2.031\end{array}$ & $\begin{array}{l}\text { ICV (Poland) } \\
\text { PIF (India) }\end{array}$ & $\begin{array}{l}=6.630 \\
=1.940\end{array}$ \\
\hline
\end{tabular}

the one stretching vibration bands to carbonyl group (1766) $\mathrm{cm}^{-1}$.The structure (C6) was confirmed by FT-IR and U.V spectrum . FT-IR spectrum (fig .9), shows the stretching vibration bands at $(3060) \mathrm{cm}^{-1}$ due to $(=\mathrm{CH})$ group, band at(3028) $\mathrm{cm}^{-1}$ due to aromatic $(\mathrm{C}-\mathrm{H})$, band at (1766) $\mathrm{cm}^{-1}$ due to
$(\mathrm{C}=\mathrm{O})$, band at $(1643) \mathrm{cm}^{-1}$ due to $(\mathrm{C}=\mathrm{N})$ and band at $(1591,1558) \mathrm{cm}^{-1}$ due to aromatic $(\mathrm{C}=\mathrm{C})$. UV spectrum of compound (C6) shows intense maxima at $(274 \mathrm{~nm})$ and $(325 \mathrm{~nm})$ due to $\pi \rightarrow \pi^{*}$ and $\mathrm{n} \rightarrow \pi^{*}$ electronic transition, respectively.

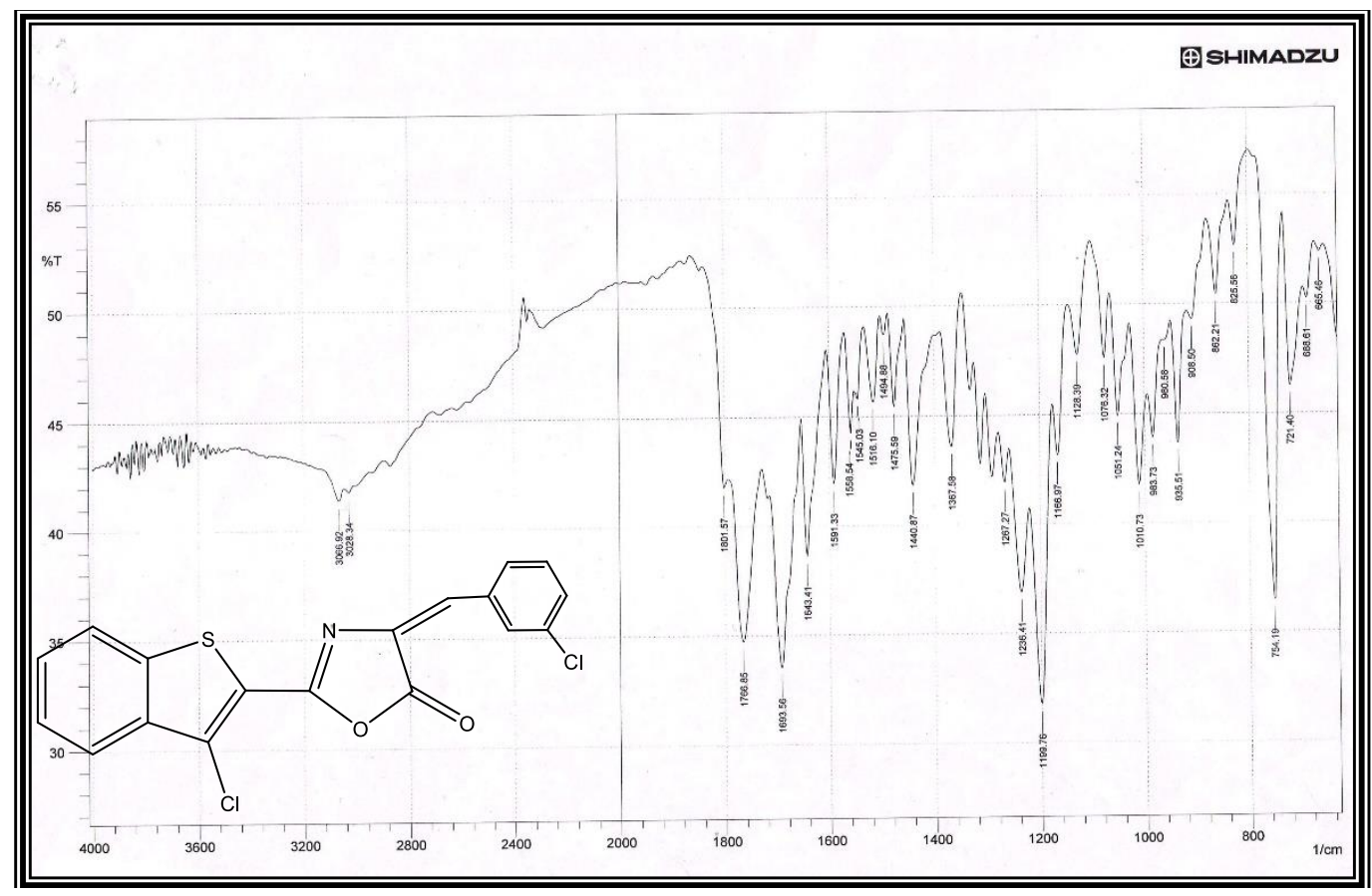

Fig. 9: The FT-IR spectrum of compound (C6).

Synthesis of 1-amino-2-(3chlorobenzo[b]thiophen-2-yl)-4-(Arylidene)-1Himidazol-5(4H)-one $(\mathrm{C} 7)$

These compounds were synthesized when Hydrazine hydrate in dry benzene was refluxed with oxazole(C6) to give (C7). Title compound was indicated by the appearance of the stretching vibration bands $(3335,3279) \mathrm{cm}^{-1}$ to $\mathrm{NH}_{2}$ groups and decreasing of stretching vibration bands $(1641) \mathrm{cm}^{-1}$ to carbonyl groups. The product (C7) was confirmed by FT-IR and U.V. spectrum. FT-IR
spectrum(Fig.10), Table (4) shows the stretching vibration bands at $(3335,3279) \mathrm{cm}^{-1}$ due to stretching vibration (asymmetric and symmetric) for $\left(\mathrm{NH}_{2}\right)$ group, band at $(3057) \mathrm{cm}^{-1}$ due to for $(=\mathrm{CH})$ group, band at $(3030) \mathrm{cm}^{-1}$ due to aromatic $(\mathrm{C}-\mathrm{H})$, band at (1641) $\mathrm{cm}^{-1}$ due to $(\mathrm{C}=\mathrm{O})$ group, band at $(1606) \mathrm{cm}^{-1}$ due to $(\mathrm{C}=\mathrm{N})$ group and band at $(1564,1514) \mathrm{cm}^{-1}$ due to for aromatic $(\mathrm{C}=\mathrm{C})$. UV spectrum of compound (C7) shows intense maxima at $(281 \mathrm{~nm})$ and $(318 \mathrm{~nm})$ due to $\pi \rightarrow \pi^{*}$ and $\mathrm{n} \rightarrow \pi^{*}$ electronic transition, respectively. 


\begin{tabular}{|c|c|c|c|c|c|c|}
\hline Impact Factor: & $\begin{array}{l}\text { ISRA (India) } \\
\text { ISI (Dubai, UAF } \\
\text { GIF (Australia) } \\
\text { JIF }\end{array}$ & $\begin{array}{l}=1.344 \\
=0.829 \\
=0.564 \\
=1.500\end{array}$ & $\begin{array}{l}\text { SIS (USA) } \\
\text { PИНЦ (Russic } \\
\text { ESJI (KZ) } \\
\text { SJIF (Morocce }\end{array}$ & $\begin{array}{l}=0.912 \\
=0.179 \\
=1.042 \\
=2.031\end{array}$ & $\begin{array}{l}\text { ICV (Poland) } \\
\text { PIF (India) }\end{array}$ & $\begin{array}{l}=6.630 \\
=1.940\end{array}$ \\
\hline
\end{tabular}

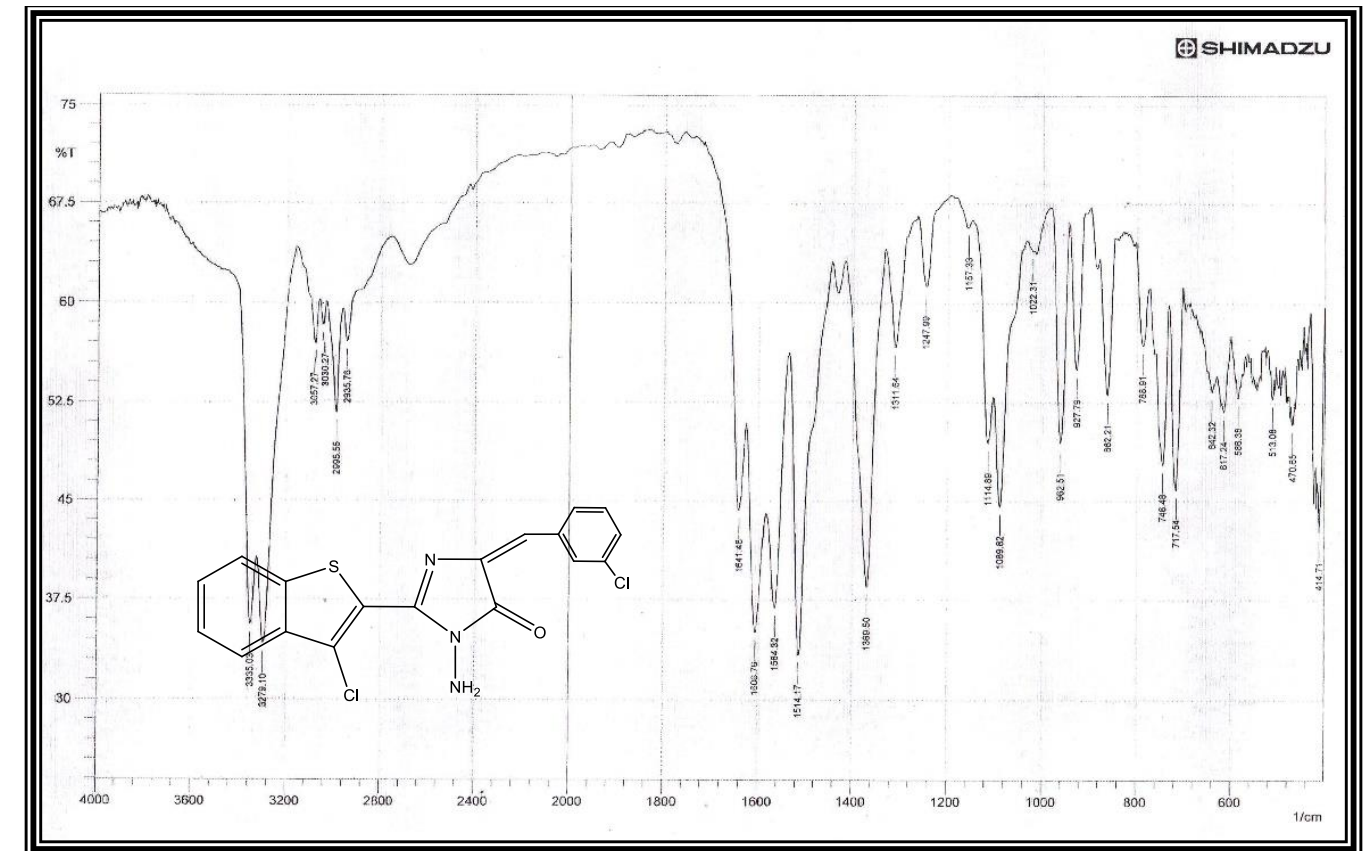

Fig. 10: The FT-IR spectrum of compound (C7).

Table (4)

IR spectral data for compounds (C5 - C7).

\begin{tabular}{|c|c|c|c|c|c|c|}
\hline \multirow{2}{*}{$\begin{array}{c}\text { Comp. } \\
\text { No }\end{array}$} & \multicolumn{5}{|c|}{ Characteristic IR bands $v\left(\mathrm{~cm}^{-1}\right)$} \\
\cline { 2 - 7 } & $=\mathrm{CH}$ & $\mathrm{CH}$ aromatic & $\mathrm{C}=\mathrm{O}$ & $\mathrm{C}=\mathrm{N}$ & $\begin{array}{c}\mathrm{C}=\mathrm{C} \\
\text { aromatic }\end{array}$ & other \\
\hline C5 & 3060 & 3028 & 1766 & 1643 & 1591,1558 & $7390(\mathrm{NH}), 3200-$ \\
\hline C6 & 3061 & $\begin{array}{c}1726 \text { acid, } 1685 \\
\text { amide }\end{array}$ & & 1597,1533 & $754(\mathrm{C}-\mathrm{Cl})$ \\
\hline C7 & 3057 & 3030 & 1641 & 1606 & 1564,1514 & $788(\mathrm{C}-\mathrm{Cl})$ \\
\hline
\end{tabular}

\subsection{Determination of antifungal activity In} Vitro:

Compounds were evaluated for inhibitory activity against Trichophyton mentagrophytes, (C4 and C7) exhibited potent antifungal activity. $T$. mentagrophytes with a world-wide distribution and a wide range of animal hosts including mice, guineapigs, kangaroos, cats, horses, sheep and rabbits. Produces inflammatory skin or scalp lesions in humans, particularly in rural workers. Kerion of the scalp and beard may occur. Invaded hairs show an ectothrix infection but do not fluoresce under Wood's ultra-violet light [13]. Evidence of derivatives possessing antifungal properties has been shown previously for compound (C4).

\subsection{Determination of antifungal activity In} vivo:

The effect of compound (C4) in treatment of skin infection in Rabbit with $T$. mentagrophytes fungus in vivo was study by using the compound as lotion as concentration $(1000 \mu \mathrm{g} / \mathrm{ml})$ subLD50 The results showed that cyclic compound had highly effect in treatment skin infection when the healing was occur after 10 days compare with control.

The disease process in dermatophytos is is unique for two reasons: Firstly, no living tissue is invaded the keratinised stratum corneum is simply colonised. However, the presence of the fungus and its metabolic products usually induces an allergic and inflammatory eczematous response in the host. The 


\begin{tabular}{|c|c|c|c|c|c|c|}
\hline Impact Factor: & $\begin{array}{l}\text { ISRA (India) } \\
\text { ISI (Dubai, UAF } \\
\text { GIF (Australia) } \\
\text { JIF }\end{array}$ & $\begin{array}{l}=1.344 \\
=0.829 \\
=0.564 \\
=1.500\end{array}$ & $\begin{array}{l}\text { SIS (USA) } \\
\text { PИНЦ (Russia) } \\
\text { ESJI (KZ) } \\
\text { SJIF (Morocco) }\end{array}$ & $\begin{array}{l}=0.912 \\
=0.179 \\
=1.042 \\
=2.031\end{array}$ & $\begin{array}{l}\text { ICV (Poland) } \\
\text { PIF (India) }\end{array}$ & $\begin{array}{l}=6.630 \\
=1.940\end{array}$ \\
\hline
\end{tabular}

type and severity of the host response is often related to the species and strain of dermatophyte causing the infection. Secondly, the dermatophytes are the only fungi that have evolved a dependency on human or animal infection for the survival and dissemination of their species [13].

\section{Conclusions}

New derivatives of imidazole were synthesized and characterized using IR,
1HNMR and GC MS spectroscopy method. The antifungal study of these derivatives againstT.mentagrophytes was studied. The novel derivatives were identified as promising antifungal agents.

\section{Acknowledgment}

This study was supported by the College of Science, Al Mustansiriyah University, Baghdad, Iraq.

\section{References:}

1) Lorch, J.M., Minnis, A.M., Meteyer, C.U., Redell, J.A., White, J.P., Kaarakka, H.M., Muller, L.K., Lindner, D.L., Verant, M.L., Shearn-Bochsler, V., Blehert, D.S. (2015) The fungus Trichophyton redellii sp. Nov. Causes skin infections that resemble white-nose syndrome of hibernating bats. J. Wildl. Dis. 51 (1): 36-47.

2) Rippon, J.W. (1982) The pathogenic fungi and pathogenic actinomycetes. Philadelphia, W.B.Saunders.

3) Aljabre, S.H.M., Richardson, M.D., Scott, E.M, Shanklans ,GS. (1992) Germination of Trichophyton mentagrophytes on human stratum corneum in vitro. $\mathrm{J}$ Med Vet Mycol; 30:145-152.

4) Gugnani HC, Oyeka CA. (1989) Foot infection due to Hendersonula toruloidea and Scytalidium hyalinum in coal miners. J Med Vet Mycol; 27:169-179.

5) Oyeka CA. (1989) Tinea capitis in Awka Local Government Area, Anambra State, Nigeria.WestAfr J Med; 9:120-123.

6) Nieboer C, Wikler J, Crijns H, et al. (1987) Incidence of tinea pedis in industrial workers using common shower rooms. Brit J Dermatol; 117:794-795.

7) Gentles JC, Holmes JG. (1957) Foot ringworm in coal miners. Brit J Industr Med; 14:22-29.

8) Liu, X.H., Tan, C.X., Weng, J.Q. (2011) Phase transfer-catalyzed, One-pot synthesis of some novel n-pyrimidinyl-n'-nicotinyl thiourea derivatives. Phosphorus, Sulfur Silicon Relat. Elem.,186, 552-557.

9) Su, N.N., Li, Y.; Yu, S.J., Zhang, X., Liu, X.H., Zhao, W.G. (2013) Microwave-assisted synthesis of some novel 1,2,3-triazoles by click chemistry, and their biological activity. Res. Chem. Intermed ., 39,759-766.

10)Liu, X.H., Pan, L., Tan, C.X., Weng, J.Q., Wang, B.L., Li, Z.M. (2011) Synthesis, crystal structure, bioactivity and DFT calculation of new oxime ester derivatives containing cyclopropane moiety. Pestic. Biochem. Physiol.,101,143-147.

11)Liu, X.H., Pan, L., Ma, Y., Weng, J.Q., Tan, C.X., Li, Y.H., Shi, Y.X., Li, B.J., Li, Z.M., Zhang, Y.G. (2011) Design, synthesis, biological activities, and 3D-QSAR of new $\mathrm{N}, \mathrm{N}$-diacylhydrazines containing2-(2,4dichlorophenoxy)propane moiety.Chem. Biol. Drug Des., 78, 689-694.

12)Chen, P.Q., Tan, C.X., Weng, J.Q., Liu, X.H. (2012) Synthesis, Structure and DFT calculation of chlorimuron-ethyl. Asian $J$. Chem., 24, 2808-2810.

13)Liu, X.H., Weng, J.Q., Tan, C.X. (2013) Synthesis, crystal structure, and fungicidal activity of 5-(4-cyclopropyl-5-((3fluorobenzyl)thio)-4H-1,2,4-triazol-3-yl)-4methyl-1,2,3-thiadiazole. J. Chem. 2013, doi:10.1155/2013/306361(2013).

14)Tong, J.Y., Shi, Y.X., Liu, X.H., Sun, N.B., Li, B.J. (2012) Synthesis and fungicidal activity of 1,2,4-triazole derivatives containing 2fluorophenyl moiety. Chin. J. Org. Chem., 32, 2373-2377.

15)Weng, J.Q., Wang, L., Liu, X.H. (2012) Synthesis, Crystal structure and herbicidal activity of a 1,2,4-triazol-5(4H)-one derivative. J. Chem. Soc. Pakistan, 34, 1248-1252.

16)Liu, X.H., Zhao, W.G., Wang, B.L., Li, Z.M. (2012) Synthesis, Bioactivity and DFT structure-activity relationship study of novel 1,2,3-thiadiazole derivatives. Res. Chem. Intermed., 38, 1999-2008.

17)Katritzky, A.R. (1984) Comprehensive Heterocyclic Chemistry., 5, 469-498(1984).

18)(2007) The Chemistry of Heterocyclic Compounds, Imidazole and Its Derivatives, Volume 6, By Klaus Hofmann ,13, John Wiley and Sons. 


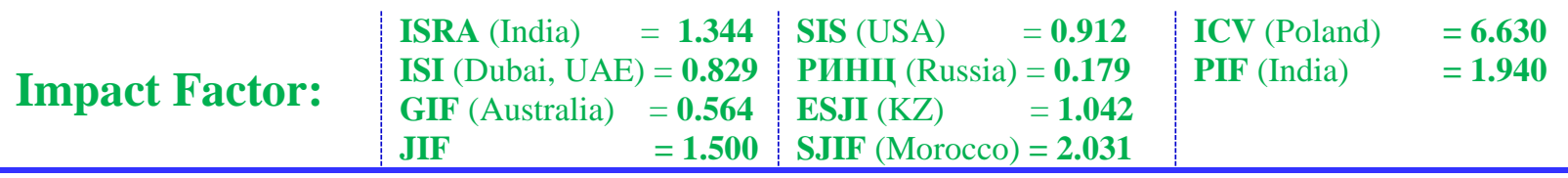

19) Bhatnagar, A., Sharma P.K., Kumar, N. (2011) A Review on "Imidazoles": Their Chemistry and Pharmacological Potentials Inter. J. Pharm Tech Res., 3( 1), 268-282.

20)Ehmann, David E. et al. (2012) Avibactam is a covalent, reversible, non- $\beta$-lactam $\beta$-lactamase inhibitor PNAS., 109(29),11663-11668.

21)Flynn, E.H. (1972) Cephalosporins and Penicillins, Chemistry and Biology. New York and London: Academic Press.

22)Rippon, J.W. (1988) Medical mycology: the pathogenic fungi and the pathogenic actinomycetes. :1-797. 3rd Edition. W.B. Saunders Co., Philadelphia, USA.

23) Stevens, D.L., Maier, K.A. and Mitten, J.E. (1987) Effect of antibiotics on toxin production and viability of Clostridium perfringens. Agents Chemother., 31(2),213-8. 